\title{
Effects of Magnesium Biotinate Supplementation on Serum Insulin, Glucose, and Lipid Parameters Along with Gene Expressions of Intermediary Metabolism in Rats
}

\section{Kazim Sahin ( $\nabla$ nsahinkm@yahoo.com )}

Department of Animal Nutrition, Faculty of Veterinary Medicine, Firat University, Elazig, Turkey https://orcid.org/0000-0001-9542-5244

\section{Cemal ORHAN}

Department of Animal Nutrition, Faculty of Veterinary Medicine, Firat University, Elazig, Turkey

\section{Osman KUCUK}

Department of Animal Nutrition and Nutritional Diseases, School of Veterinary Medicine, Erciyes University, Kayseri, Turkey

\section{Mehmet TUZCU}

Firat Universitesi

\section{Nurhan SAHIN}

Department of Animal Nutrition, Faculty of Veterinary Medicine, Firat University, Elazig, Turkey

\section{Sara PEREZ OJALVO}

Research and Development, Nutrition 21, LLC, New York, USA

\section{James R KOMOROWSKI}

Research and Development, Nutrition 21, LLC, New York, USA

\section{Research}

Keywords: Biotin, Insulin, Magnesium biotinate, Glucose, Lipid, Gene expressions

Posted Date: May 20th, 2020

DOI: https://doi.org/10.21203/rs.3.rs-29601/v1

License: (c) (i) This work is licensed under a Creative Commons Attribution 4.0 International License. Read Full License 


\section{Abstract}

Background: The objective of this work was to investigate the effects of a novel form of biotin (magnesium biotinate) at various levels on body weight, serum concentrations of glucose, insulin, cholesterol, and triglycerides, and liver expression of lipid metabolism-related genes such as SREBP-1c, FAS, AMPK-a1, ACC-1, ACC-2, PC, PCC and MCC in rats.

Methods: A total of 42 male Sprague-Dawley rats were divided into six treatment groups and fed a standard diet-based egg white powdered diet supplemented with either commercial biotin (d-biotin) at $0.01,1$ or $100 \mathrm{mg} / \mathrm{kg}$ body weight or a novel form of biotin (magnesium biotinate) at $0.01,1$, or 100 $\mathrm{mg} / \mathrm{kg}$ bodyweight for 35 days. The doses used at $0.01,1$ and $100 \mathrm{mg}$ from each source represented a standard dietary dose (control), high dietary dose, and pharmacologic dose, respectively.

Results: Bodyweight changes, feed intake, serum concentrations of glucose, insulin, creatine, and urea, and enzyme activities of ALT and AST were similar among treatments $(P>0.05)$. Serum total cholesterol and triglyceride concentrations of the rats decreased with biotin supplementation from both sources $(P<$ 0.05). Concentrations were significantly lower with magnesium biotinate when comparing the $1 \mathrm{mg} / \mathrm{kg}$ dose groups $(P<0.05)$. Serum, liver, brain biotin concentrations, and liver cGMP contents were greater when rats were treated with magnesium biotinate versus d-biotin, particularly when comparing the 1 $\mathrm{mg} / \mathrm{kg}$ and $100 \mathrm{mg} / \mathrm{kg}$ dose groups $(P<0.05)$. Both forms of biotin decreased the liver gene expression of SREBP-1C and FAS and increased liver gene expression of AMPK-a1, ACC-1, ACC-2, PCC and MCC (P< 0.05). The magnitudes of responses were more emphasized with magnesium biotinate. Liver PC gene expression increased with biotin supplementation with no regard to dose or biotin form $(P>0.05)$.

Conclusion: Results of the present work revealed that a new form of biotin, magnesium biotinate, compared with a commercial d-biotin, is more effective in reducing serum lipid concentrations and in regulating gene expressions of intermediary metabolism-related biomarkers.

\section{Background}

Biotin, also known as vitamin $\mathrm{B} 7$ or vitamin $\mathrm{H}$, is an essential water-soluble vitamin. Biotin is a covalently bound coenzyme to five biotin-dependent carboxylases, which are involved in essential biological processes including fatty acid synthesis, gluconeogenesis, and amino acid metabolism [1]. Biotin is also functional in cell signaling, modulations of the expression of up to 2000 genes, immunity, and chromatin structure [2,3]. Biotin administration has been shown to decrease serum concentrations of triglycerides $[4,5,6]$ cholesterol [7], and free fatty acids [8, 9] in human and animal studies. The mechanism by which biotin is involved in the lipid homeostasis is mostly related to its presence in carboxylases. Biotindependent carboxylases include acetyl CoA carboxylase (ACC), propionyl CoA carboxylase (PCC), 3methylcrotonyl-CoA carboxylase (MCC), geranyl-CoA carboxylase (GCC), and long-chain acyl-CoA carboxylase (LCC), as well as small organic compounds such as pyruvate carboxylase (PC) and urea carboxylase (UC) [10]. 
Acetyl CoA carboxylase is the key enzyme involved in the synthesis of fatty acids. Two isoforms of ACC are ACC-1 (also known as ACCa) and ACC-2 (also known as ACC 3 ). ACC-1 is the key enzyme in the liver and adipose tissues of mammals catalyzing long-chain fatty acid biosynthesis, whereas ACC- 2 is active mainly in the heart, muscles, and liver tissues $[10,11]$. Pyruvate carboxylase catalyzes the conversion of pyruvate to oxaloacetate, and thus is crucial in intermediary metabolism, governing fuel partitioning toward gluconeogenesis, lipogenesis, and insulin secretion [12]. Propionyl-CoA carboxylase is an important enzyme that contributes to the catabolism of cholesterol and odd chain fatty acids as well as certain amino acids (valine, methionine, isoleucine, and threonine) [10]. 3-Methylcrotonyl-CoA carboxylase is crucial for the catabolism of leucine and isovalerate [13].

Several factors are also involved in lipid metabolism and its regulation. Sterol regulatory element-binding proteins (SREBPs) adjust the synthesis and cellular uptake of cholesterol and fatty acids [14]. In addition, fatty acid synthase (FAS) catalyzes fatty acid synthesis (de novo), thus regulating energy homeostasis by transforming the excess food consumed into lipids (mainly palmitate) for storage. This process supplies energy when needed via beta-oxidation in animal and human tissues [15]. AMP-activated protein kinase (AMPK) acts as a key enzyme in skeletal muscle fat metabolism. AMPK regulates cellular energy homeostasis through mainly activating glucose and fatty acid uptake and oxidation when cellular energy is low [16]. AMPK protein complex consists of $a, \beta$, and $y$ subunits. Alpha (a) subunits have the catalytic domain of the AMPK.

Biotin is required for maintaining normal glucose metabolism through regulating the expression of insulin receptors [17] and improving beta cell functions in pancreatic islets [18, 19], increasing insulin secretion [20]. The beneficial effect of biotin in hyperglycemia has also been confirmed in both types 1 and 2 diabetes [21].

For adults, the U.S Recommended Dietary Allowance (RDA) for biotin is $30 \mu \mathrm{g} /$ day. While biotin intake is 35-70 $\mu \mathrm{g} /$ day with a typical Western diet [22], biotin supplementation has still been shown to provide various benefits. For instance, biotin supplementation at $6 \mathrm{mg} / \mathrm{kg}$ resulted in improvements in glucose metabolism, measured by increased IRS-1 liver expressions in rats [23]. Moreover, biotin supplementation increased serum glucose, cholesterol, triglycerides, creatinine, and MDA concentrations in diabetic rats supplemented with $300 \mu \mathrm{g}$ biotin/kg BW [8]. High doses of biotin have also been studied in the treatment of multiple sclerosis [24]. However, the full mechanisms by which biotin exerts its effects on lipid, carbohydrate, and amino acid metabolism through gene expressions are still being elucidated, particularly with a new form of biotin, called magnesium biotinate (MB). Magnesium biotinate is a novel biotin complex of magnesium and biotin that has been shown to be 40 times more soluble than commercial biotin, as well as having greater tissue and serum uptake [25]. Therefore, the objectives of the present work were; 1 ) to investigate the effects of magnesium biotinate as compared to commercial biotin at various levels, including pharmacological doses, on body weight, serum concentrations of glucose, insulin, cholesterol, and triglycerides, and serum and tissue biotin concentrations in rats and 2) to observe changes in the gene expression of intermediary metabolism-related genes such as SREBP-1c, FAS, AMPK-alpha1, ACC-1, ACC-2, PC, PCC and MCC in the rat liver. 


\section{Methods}

\section{Animals and diets}

Male Sprague-Dawley rats ( $n=42,8$ weeks old) were provided from the Laboratory Animal Research Center, Firat University (Elazig, Turkey). The animals were kept in a room with standard conditions (22 \pm $2{ }^{\circ} \mathrm{C}$ temperature, $55 \pm 5 \%$ humidity, a 12-h light-12-h dark cycle). The ethical permission of the experiment was obtained from the Animal Experimentation Ethics Committee of Firat University (2017/84-166) according to the relevant laws, guidelines, and restrictions.

The rats were offered ad libitum water and a standard diet with minor modifications formulated by the American Institute of Nutrition. The diet contained a protein source of only spray-dried egg white avidin to bind biotin to standardize biotin absorption across groups (egg white avidin protein binds about $1.44 \mathrm{mg}$ biotin/ $\mathrm{kg}$ of purified diet). The biotin concentrations of the present work were adequate for avidin binding.

The rats were randomly assigned to one of six treatment groups ( $n=7$ per group) and fed a standard egg white powdered diet supplemented with either commercial biotin (d-biotin) at $0.01,1$, or $100 \mathrm{mg} / \mathrm{kg}$ body weight (BW), or magnesium biotinate at $0.01,1$, or $100 \mathrm{mg} / \mathrm{kg} \mathrm{BW}$. The doses used at $0.01,1$ and $100 \mathrm{mg} / \mathrm{kg} \mathrm{BW}$ from each source represented a standard dietary dose, high dietary dose, and pharmacologic dose, respectively. Magnesium biotinate contains $86 \%$ biotin. Therefore, any effects detected upon magnesium biotinate supplementation should be mainly attributed to biotin, not magnesium.

The duration of the study was 35 days. Bodyweight changes as initial and final, as well as feed intake, were recorded weekly. At the end of the study, upon overnight fasting, blood samples were collected through the Cardiac Puncture Blood Collection method. The cervical dislocation was used for animal euthanasia, and liver and brain samples were obtained for analyses.

\section{Laboratory analyses}

Sera samples out of the blood were yielded through centrifugation at $3.000 \times \mathrm{g}$ for $10 \mathrm{~min}$. Serum glucose, creatinine, urea, total cholesterol, and triglycerides levels, as well as enzyme activities of ALT and AST, were measured using an automated analyzer (Samsung LABGEOPT10, Samsung Electronics Co, Suwon, Korea). A rat insulin kit was used to analyze the insulin levels (Linco Research Inc, St. Charles, MO, USA) with an ELISA instrument (Elx-800, Bio-Tek Instruments Inc, Vermont, USA). The assay sensitivity was $0.35 \mathrm{ng} / \mathrm{mL}$. Inter- and Intra- assay constants were $3.2 \%$ and $6.9 \%$.

For determination of liver the cGMP, samples were diced into small pieces in cold PBS and homogenized in a cold $100 \mathrm{mM}$ phosphate buffer at $16.000 \mathrm{rpm}$ for $3 \mathrm{~min}$ (pH 7.5). The samples were re-homogenized with a glass homogenizer on ice and subjected to two freeze-thaw cycles accompanied by ultrasonication. The concentration of cGMP was detected using a commercially available assay kit 
(LSBio, Seattle,WA, USA). The inter- and intra- assay constants were CV $<10 \%$ and inter-assay $<12 \%$, respectively.

For the assay of serum biotin concentration, samples were ultrafiltered as earlier described [26]. Tissue samples $(300 \mathrm{mg}$ ) were processed in 5 volumes of ice-cold homogenization buffer $(300 \mathrm{mmol} / \mathrm{L}$ mannitol, $10 \mathrm{mmol} / \mathrm{L}$ HEPES, pH 7.2, $1 \mathrm{mmol} / \mathrm{L}$ EDTA and protease inhibitor cocktail). The samples were then centrifuged at $15.0003 \mathrm{xg}$ for $30 \mathrm{~min}$ at $4{ }^{\circ} \mathrm{C}$. Before the biotin measurement, the supernatant was ultrafiltered. The pellet was brought to a concentration of $40 \mathrm{~g} / \mathrm{L}$ in a homogenization buffer. The tissue samples were promptly frozen in a mixture of dry ice and isopropanol and stored at $-80^{\circ} \mathrm{C}$ until analyzing. Serum, liver, and brain biotin levels were analyzed by HPLC (Shimadzu, Kyoto, Japan) as earlier defined with minor modifications [27, 28]. The C18-ODS-3 reversed-phase column $(250 \times 4.6 \mathrm{~mm}$, $5 \mathrm{~m}$ ) and biotin-containing chromatography fractions were used in HPLC. A stream of nitrogen was used to dry the samples before analyzing them.

\section{Western blot analysis}

The western blotting technique was used to detect specific proteins with procedures described earlier [29]. Liver samples were pooled and homogenized in $1 \mathrm{ml}$ ice-cold hypotonic buffer A including $10 \mathrm{mM}$ HEPES (pH 7.8), $10 \mathrm{mM} \mathrm{KCl}, 2 \mathrm{mM} \mathrm{MgCl} 2,1 \mathrm{mM}$ DTT, $0.1 \mathrm{mM}$ EDTA, and $0.1 \mathrm{mM}$ phenylmethylsulfonyl-fluoride (PMSF). Eighty $\mu \mathrm{l}$ of $10 \%$ Nonidet P-40 (NP-40) solution was added to the homogenates and the mixture then was implemented with centrifugation for $2 \mathrm{~h}$ at $14,000 \mathrm{~g}$. Five-hundred $\mu$ l of buffer A plus $40 \mu \mathrm{l}$ of $10 \%$ NP-40 was used to wash the precipitates containing nuclei. The precipitates were then centrifuged and resuspended in $200 \mu \mathrm{l}$ of buffer $\mathrm{C}$ [ $50 \mathrm{mM}$ HEPES (pH 7.8), $50 \mathrm{mM} \mathrm{KCl}, 300 \mathrm{mM} \mathrm{NaCl}, 0.1 \mathrm{mM}$ EDTA, $1 \mathrm{mM}$ DTT, $0.1 \mathrm{mM}$ PMSF, $20 \%$ glycerol], and centrifuged for $30 \mathrm{~min}$ at $14.800 \mathrm{~g}$. The supernatant was removed to new tubes. Western blot analyses were run on the tissue homogenates for SREBP-1c, fatty acid synthase (FAS), (Thr172)-phosphorylated AMPK-a form, as well as acetyl-CoA carboxylase 1 (ACC 1), acetyl-CoA carboxylase 2 (ACC 2), pyruvate carboxylase (PC), propionyl-CoA carboxylase (PCC), and 3methylcrotonyl-CoA carboxylase (MCC), and $\beta$-actin. Protein concentration was measured using the Lowry method. A pool of tissue samples was created with the same amounts of protein $(50 \mu \mathrm{g})$ and the samples were electrophoresed (12\% SDS-PAGE gels) followed by transfer to nitrocellulose membrane (Schleicher and Schuell Inc., Keene, NH, USA). The primary antibodies against SREBP-1c, FAS, (Thr172)-pAMPK-a, ACC 1 and 2, PC, PCC, and MCC and $\beta$-actin were delivered (Abcam Inc., UK). The primary antibody was reduced in strength $(1: 1000)$ in the same buffer containing $0.05 \%$ Tween-20. The antibody with the nitrocellulose membrane was incubated overnight at $4{ }^{\circ} \mathrm{C}$. After washing, the blots were incubated with goat anti-mouse IgG (horseradish peroxidase-conjugated secondary antibody) with a dilution of 1:5000 (Abcam, Cambridge, UK). To avoid data reproducibility, the blots were run several times. Protein bands were quantified via scanning densitometry using an image analysis system (Image J; National Institute of Health, Bethesda, USA). The protein bands were normalized by the corresponding $\beta$ actin band values and compared with the control group. 


\section{Statistical analysis}

One-way ANOVA was used to analyze the data using SPSS for Windows version 21.0 (IBM Corp., Armonk, NY, USA). The Tukey post hoc test was also applied among treatment groups. $P<0.05$ was the level of statistical significance. Data were reported as a mean and standard error of the mean.

\section{Results And Discussion}

Initial body weights, as intended, as well as final body weights and feed intake of rats, were similar among treatments $(P>0.05$; Table 1$)$. Similar to the results of the present work, unchanged final body weights of rats fed a diet supplemented with $6 \mathrm{mg}$ biotin/ $\mathrm{kg}$ of diet [23] and of mice fed a diet supplemented with $97.70 \mathrm{mg}$ of free biotin/ $\mathrm{kg}$ diet [30,31] has been reported. 
Table 1

Effects of biotin supplementation as the commercial form or magnesium biotinate on live weight changes and serum metabolites.

\begin{tabular}{|c|c|c|c|c|c|c|c|}
\hline \multirow[t]{2}{*}{ Items } & \multicolumn{6}{|c|}{ Treatments* } & \multirow[t]{2}{*}{$-P-$} \\
\hline & B 0 & B 1 & B 100 & MgB 0 & MgB 1 & MgB 100 & \\
\hline $\begin{array}{l}\text { Initial Body } \\
\text { Weight, g }\end{array}$ & $\begin{array}{l}248.43 \\
\pm 4.42\end{array}$ & $\begin{array}{l}251.43 \pm \\
4.83\end{array}$ & $\begin{array}{l}246.71 \pm \\
3.43\end{array}$ & $\begin{array}{l}252.29 \pm \\
2.29\end{array}$ & $\begin{array}{l}249.86 \pm \\
5.91\end{array}$ & $\begin{array}{l}251.29 \pm \\
4.51\end{array}$ & 0.946 \\
\hline $\begin{array}{l}\text { Final Body } \\
\text { Weight, g }\end{array}$ & $\begin{array}{l}295.43 \\
\pm 4.87\end{array}$ & $\begin{array}{l}298.57 \pm \\
4.70\end{array}$ & $\begin{array}{l}294.00 \pm \\
5.57\end{array}$ & $\begin{array}{l}296.29 \pm \\
5.73\end{array}$ & $\begin{array}{l}297.43 \pm \\
5.01\end{array}$ & $\begin{array}{l}299.29 \pm \\
4.27\end{array}$ & 0.977 \\
\hline Feed Intake, g & $\begin{array}{l}24.00 \pm \\
0.65\end{array}$ & $\begin{array}{l}24.86 \pm \\
0.59\end{array}$ & $\begin{array}{l}24.43 \pm \\
1.07\end{array}$ & $\begin{array}{l}24.71 \pm \\
0.87\end{array}$ & $\begin{array}{l}24.14 \pm \\
0.55\end{array}$ & $\begin{array}{l}24.43 \pm \\
0.57\end{array}$ & 0.963 \\
\hline $\begin{array}{l}\text { Glucose, } \\
\text { mg/dL }\end{array}$ & $\begin{array}{l}89.00 \pm \\
2.44\end{array}$ & $\begin{array}{l}89.29 \pm \\
2.74\end{array}$ & $\begin{array}{l}91.71 \pm \\
2.35\end{array}$ & $\begin{array}{l}90.71 \pm \\
3.11\end{array}$ & $\begin{array}{l}83.57 \pm \\
3.92\end{array}$ & $\begin{array}{l}87.43 \pm \\
3.18\end{array}$ & 0.480 \\
\hline Insulin, mIU/L & $\begin{array}{l}14.10 \pm \\
0.92\end{array}$ & $\begin{array}{l}16.13 \pm \\
0.71\end{array}$ & $\begin{array}{l}15.96 \pm \\
1.10\end{array}$ & $\begin{array}{l}14.77 \pm \\
1.67\end{array}$ & $\begin{array}{l}17.33 \pm \\
1.04\end{array}$ & $\begin{array}{l}15.67 \pm \\
1.05\end{array}$ & 0.428 \\
\hline ALT, U/L & $\begin{array}{l}82.29 \pm \\
1.60\end{array}$ & $\begin{array}{l}81.14 \pm \\
4.66\end{array}$ & $\begin{array}{l}85.57 \pm \\
2.44\end{array}$ & $\begin{array}{l}83.43 \pm \\
3.27\end{array}$ & $\begin{array}{l}82.71 \pm \\
2.95\end{array}$ & $\begin{array}{l}81.43 \pm \\
2.96\end{array}$ & 0.928 \\
\hline AST, U/L & $\begin{array}{l}126.29 \\
\pm 6.23\end{array}$ & $\begin{array}{l}121.86 \pm \\
5.80\end{array}$ & $\begin{array}{l}123.57 \pm \\
10.39\end{array}$ & $\begin{array}{l}121.86 \pm \\
11.92\end{array}$ & $\begin{array}{l}122.00 \pm \\
10.40\end{array}$ & $\begin{array}{l}118.14 \pm \\
6.05\end{array}$ & 0.993 \\
\hline $\begin{array}{l}\text { Creatine, } \\
\mathrm{mg} / \mathrm{dL}\end{array}$ & $\begin{array}{l}0.47 \pm \\
0.06\end{array}$ & $\begin{array}{l}0.41 \pm \\
0.08\end{array}$ & $\begin{array}{l}0.43 \pm \\
0.06\end{array}$ & $\begin{array}{l}0.44 \pm \\
0.04\end{array}$ & $\begin{array}{l}0.44 \pm \\
0.11\end{array}$ & $\begin{array}{l}0.40 \pm \\
0.05\end{array}$ & 0.987 \\
\hline Urea, mg/dL & $\begin{array}{l}23.87 \pm \\
2.04\end{array}$ & $\begin{array}{l}22.44 \pm \\
2.23\end{array}$ & $\begin{array}{l}23.09 \pm \\
0.99\end{array}$ & $\begin{array}{l}22.80 \pm \\
1.83\end{array}$ & $\begin{array}{l}23.27 \pm \\
2.22\end{array}$ & $\begin{array}{l}24.16 \pm \\
1.73\end{array}$ & 0.988 \\
\hline $\begin{array}{l}\text { Total } \\
\text { cholesterol, } \\
\text { mg/dL }\end{array}$ & $\begin{array}{l}73.00 \pm \\
1.81^{\mathrm{a}}\end{array}$ & $\begin{array}{l}64.57 \pm \\
1.86^{\mathrm{b}}\end{array}$ & $\begin{array}{l}64.00 \pm \\
1.98^{\mathrm{b}}\end{array}$ & $\begin{array}{l}74.00 \pm \\
2.56^{\mathrm{a}}\end{array}$ & $\begin{array}{l}54.29 \pm \\
1.66^{c}\end{array}$ & $\begin{array}{l}60.86 \pm \\
1.87^{\mathrm{bc}}\end{array}$ & 0.0001 \\
\hline $\begin{array}{l}\text { Triglyceride, } \\
\mathrm{mg} / \mathrm{dL}\end{array}$ & $\begin{array}{l}68.00 \pm \\
2.46^{\mathrm{a}}\end{array}$ & $\begin{array}{l}59.29 \pm \\
4.86^{\mathrm{ab}}\end{array}$ & $\begin{array}{l}60.29 \pm \\
1.54^{\mathrm{ab}}\end{array}$ & $\begin{array}{l}66.00 \pm \\
3.18^{\mathrm{a}}\end{array}$ & $\begin{array}{l}45.14 \pm \\
2.52^{c}\end{array}$ & $\begin{array}{l}48.14 \pm \\
1.91^{b c}\end{array}$ & 0.0001 \\
\hline \multicolumn{8}{|c|}{$\begin{array}{l}\text { * Dietary treatments contained biotin supplements as either commercial biotin (d-biotin) at } 0.01 \text { (B0), } \\
1 \text { (B1) and } 100 \text { (B100) } \mathrm{mg} / \mathrm{kg} \text { body weight or a new form of biotin (magnesium biotinate) at } 0.01 \\
\text { (MgB0), } 1(\mathrm{MgB} 1) \text {, and } 100 \text { (MgB100) } \mathrm{mg} / \mathrm{kg} \text { body weight. The doses used at } 0.01,1 \text {, and } 100 \mathrm{mg} \text { of } \\
\text { biotin supplementations from each source represented standard dietary dose (control), high dietary } \\
\text { dose, and pharmacologic dose, respectively. Statistical comparisons are indicated with different } \\
\text { superscript (a-c) in the same row }(P<0.05 \text {; ANOVA and Tukey's post-hoc test). Mean values are } \\
\text { demonstrated with } \pm \text { standard deviations. ALT: Alanine aminotransferase; AST: Aspartate } \\
\text { aminotransferase. }\end{array}$} \\
\hline
\end{tabular}

In the present study, neither form of biotin influenced $(P>0.05)$ serum glucose or insulin concentrations. Although decreases in serum glucose concentrations in rats fed a diet supplemented with biotin have been reported [23], Lazo de la Vega-Monroy et al. [30] found increases in elevated glucose-stimulated serum insulin concentrations, but no changes in fasting glucose concentrations or insulin tolerance in mice fed a diet supplemented with biotin. Enhanced fasting serum glucose levels have been observed 
with biotin supplementation in individuals with Type 2 diabetes who had low serum biotin concentrations before supplementation [21]. However, biotin administration $(6.14 \mu \mathrm{mol} / \mathrm{d})$ for 28 days to individuals with Type 2 diabetes did not change concentrations of glucose, insulin, triacylglycerol, or cholesterol [32]. Inconsistent results from the present work and the literature in experimental animals and individuals with Type 2 diabetes [21, 23, 30,32] could have been due to differences in biotin doses, duration of supplementation, or the severity of diabetes, among others.

Biotin supplementation has been shown to increase glucose-stimulated insulin secretion in rats [33] and mice [30] via affecting morphology and number of cells in the pancreas. Tixi-Verdugo et al. [34] found that mice fed a diet supplemented with $100 \mathrm{mg}$ of biotin/ $\mathrm{kg}$ diet had greater beta-cell proportions (\%) and an elevated number of islets per pancreatic area. Biotin is known to improve glycemic control through stimulating pancreatic and hepatic glucokinases while inhibiting the hepatic gluconeogenic enzyme phosphoenolpyruvate carboxykinase [35]. Glucose is considered the major lipogenic substrate for most tumor cells, which have greater lipid synthesis and requirement for amino acids [36]. Therefore, supplementing biotin can be indirectly involved in the prevention and therapy of cancer, diabetes, obesity, and other diseases.

Serum ALT and AST enzyme activities, as well as concentrations of creatine and urea, remained similar among treatments $(P>0.05)$. Similarly, [31] found no changes in ALT activity of urea concentrations but greater AST enzyme activities in biotin-supplemented mice ( $97.70 \mathrm{mg}$ of free biotin $/ \mathrm{kg}$ diet). Although greater AST enzyme activity was found in the biotin-supplemented group, the values were within the normal range (55.0-352 U/L). Results from the present work and the literature [31] indicate that neither pharmacological doses of commercial d-biotin or magnesium biotinate influence indicators of liver damage.

Serum total cholesterol and triglyceride concentrations in the rats decreased with biotin supplementation from both sources $(P<0.05)$. However, supplementing with magnesium biotinate provided greater decreases in blood lipid concentrations, particularly with the $1 \mathrm{mg} / \mathrm{kg}$ dose $(P<0.05)$, compared to commercial biotin. In accordance with the results of the present work, Turgut et al. [23] also reported decreases in serum concentrations of cholesterol and triglyceride in rats fed a diet supplemented with $6 \mathrm{mg} / \mathrm{kg}$ biotin. Larrieta et al. [5] also found reduced serum triglyceride concentrations in mice fed a diet supplemented with $97.7 \mathrm{mg}$ of free biotin/ $\mathrm{kg}$ diet. Similarly, plasma concentrations of triacylglycerol and VLDL-cholesterol were reported to decrease in biotin-supplemented $(61.4 \mu \mathrm{mol} /$ day $)$ individuals with Type 2 diabetes [4].

As expected, biotin supplementation with both forms resulted in increases in serum, liver, and brain biotin concentrations $(P<0.05$, Table 2$)$. However, biotin concentrations of the blood and the organs were greater with magnesium biotinate compared with the same doses of commercial d-biotin, particularly in the 1 and $100 \mathrm{mg} / \mathrm{kg}$ BW groups $(P<0.05)$. Similarly, elevated serum biotin concentrations were also reported in a previous study where mice were fed a diet supplemented with biotin [30]. 
Table 2

Effects of biotin supplementation as the commercial form or magnesium biotinate on serum, liver and brain biotin concentrations and liver cGMP contents.

\begin{tabular}{|c|c|c|c|c|c|c|c|}
\hline \multirow[t]{2}{*}{ Items } & \multicolumn{6}{|c|}{ Treatments* } & \multirow{2}{*}{$-P-$} \\
\hline & B 0 & B 1 & B 100 & MgB 0 & MgB 1 & MgB 100 & \\
\hline $\begin{array}{l}\text { Serum biotin, } \\
\mathrm{nmol} / \mathrm{L}\end{array}$ & $\begin{array}{l}23.65 \\
\pm 2.60^{c}\end{array}$ & $\begin{array}{l}136.67 \\
\pm 2.73^{c}\end{array}$ & $\begin{array}{l}3517.14 \pm \\
87.93^{\mathrm{b}}\end{array}$ & $\begin{array}{l}23.41 \\
\pm 2.31^{\mathrm{c}}\end{array}$ & $\begin{array}{l}171.13 \\
\pm 3.02^{\mathrm{C}}\end{array}$ & $\begin{array}{l}5161.43 \pm \\
250.96^{\mathrm{a}}\end{array}$ & 0.0001 \\
\hline $\begin{array}{l}\text { Liver biotin, } \\
\mathrm{nmol} / \mathrm{g}\end{array}$ & $\begin{array}{l}0.02 \pm \\
0.01^{\mathrm{e}}\end{array}$ & $\begin{array}{l}0.56 \pm \\
0.04^{d}\end{array}$ & $\begin{array}{l}1.38 \pm \\
0.02^{b}\end{array}$ & $\begin{array}{l}0.03 \pm \\
0.01^{\mathrm{e}}\end{array}$ & $\begin{array}{l}0.71 \pm \\
0.03^{c}\end{array}$ & $\begin{array}{l}1.62 \pm \\
0.02^{\mathrm{a}}\end{array}$ & 0.0001 \\
\hline $\begin{array}{l}\text { Brain biotin, } \\
\mathrm{nmol} / \mathrm{g}\end{array}$ & $\begin{array}{l}0.14 \pm \\
0.01^{\mathrm{e}}\end{array}$ & $\begin{array}{l}0.42 \pm \\
0.05^{d}\end{array}$ & $\begin{array}{l}1.37 \pm \\
0.04^{b}\end{array}$ & $\begin{array}{l}0.14 \pm \\
0.01^{\mathrm{e}}\end{array}$ & $\begin{array}{l}0.66 \pm \\
0.04^{c}\end{array}$ & $\begin{array}{l}1.65 \pm \\
0.03^{a}\end{array}$ & 0.0001 \\
\hline $\begin{array}{l}\text { Liver cGMP, } \\
\mathrm{pmol} / \mathrm{mg} \text { protein }\end{array}$ & $\begin{array}{l}8.46 \pm \\
0.26^{d}\end{array}$ & $\begin{array}{l}12.01 \pm \\
0.26^{\mathrm{c}}\end{array}$ & $\begin{array}{l}14.68 \pm \\
0.32^{\mathrm{b}}\end{array}$ & $\begin{array}{l}8.60 \pm \\
0.28^{d}\end{array}$ & $\begin{array}{l}13.04 \pm \\
0.98^{\mathrm{bc}}\end{array}$ & $\begin{array}{l}17.07 \pm \\
0.28^{\mathrm{a}}\end{array}$ & 0.0001 \\
\hline \multicolumn{8}{|c|}{$\begin{array}{l}\text { *Dietary treatments contained biotin supplements as either commercial biotin (d-biotin) at } 0.01 \text { (B0), } 1 \\
\text { (B1) and } 100(\mathrm{~B} 100) \mathrm{mg} / \mathrm{kg} \text { body weight or a new form of biotin (magnesium biotinate) at } 0.01 \\
(\mathrm{MgB0}), 1(\mathrm{MgB} 1) \text {, and } 100(\mathrm{MgB} 100) \mathrm{mg} / \mathrm{kg} \text { body weight. The doses used at } 0.01,1 \text {, and } 100 \mathrm{mg} \text { of } \\
\text { biotin supplementations from each source represented standard dietary dose (control), high dietary } \\
\text { dose, and pharmacologic dose, respectively. Statistical comparisons are indicated with different } \\
\text { superscript (a-e) in the same row }(P<0.05 \text {; ANOVA and Tukey's post-hoc test). Mean values are } \\
\text { demonstrated with } \pm \text { standard deviations. }\end{array}$} \\
\hline
\end{tabular}

Cyclic guanosine monophosphate (cGMP) functions as anti-apoptotic and anti-inflammatory in cells and regulates multiple physiologic processes in the cardiovascular system [37]. Biotin supplementation to the diet of mice has been shown to decrease blood triglyceride concentrations through increased cGMP content $[6,9]$. Comparable to the results reported by other researchers $[6,9]$, liver cGMP contents of animals in the present work also increased with biotin supplementation. However, liver cGMP contents were higher in rats supplemented with magnesium biotinate compared with the same doses of commercial d-biotin, particularly when comparing the $100 \mathrm{mg} / \mathrm{kg} \mathrm{BW}$ groups $(P<0.05)$. Cyclic guanosine monophosphate has also been proposed to have a substantial effect on beta-cell functions [38]. In the present study, although cGMP contents of the liver increased with biotin supplementation, neither serum glucose nor insulin concentrations were significantly altered.

Biotin is thought to reduce levels of blood lipids (hypotriglyceridemia) and glucose (hypoglycemia) through regulation of the mRNA abundance of lipogenic enzymes and transcription factors such as SREBP-1c, FAS, ACC, and pyruvate kinase, among others [39]. One of the main objectives of the present work was to detail the effects of biotin on such factors in order to determine the mechanism by which biotin, particularly the new form of biotin, works. Liver gene expression of SREBP-1c and FAS decreased while expression of AMPK-alpha increased with both biotin forms $(P<0.05$; Fig. 1$)$. The magnitudes of responses were more emphasized with magnesium biotinate, particularly when comparing the $1 \mathrm{mg} / \mathrm{kg}$ dose groups for SREBP-1c and the $100 \mathrm{mg} / \mathrm{kg}$ dose groups for FAS and AMPK-alpha $(P<0.05)$. Gene expression of liver ACC-1, ACC-2, PCC, and MCC increased ( $P<0.05$; Fig. 2$)$ with both biotin forms. This 
effect was more apparent with magnesium biotinate when compared to similar doses of commercial dbiotin $(P<0.05)$. The liver $P C$ gene expression increased with biotin supplementation, with no differences found from dose or biotin form $(P>0.05)$.

The functions of SREBP-1c involve activating several enzymes including FAS and ACC in catalyzing various steps in fatty acid and TG synthesis pathways [40]. Therefore, decreases in both SREBP-1c and FAS were consistent with reduced serum lipid concentrations of total cholesterol and triglycerides seen in the present work. Over-nutrition or intake of energy-dense molecules (sugar and saturated fatty acids) results in an increase in SREBP-1c expression and consequently lipogenesis in the liver [41]. Through regulation of energy metabolism, biotin supplementation, particularly magnesium biotinate, can reduce SREBP-1c expression and consequently reduce serum lipid concentrations.

Low cellular energy causes activation of AMPK which inactivates both ACC isoforms, ACC-1 and ACC-2, resulting in reduced de novo lipogenesis and increased fatty acid oxidation [42]. Similarly, biotin supplementation in mice and rats has been reported to increase the active form of AMPK, which phosphorylates ACC-1 and ACC-2, resulting in decreases in the rate of lipid synthesis and increases in fatty acid oxidation rates $[43,44]$. Biotin supplementation in mice has also been shown to increase the gene expression of the active form of AMPK and decrease FAS and SREBP-1c expression [6, 44]. MorenoMéndez et al. [44] found that ACC-1 and FAS reduced the acetate incorporations into total lipid fractions in response to biotin supplementation, resulting in lower fatty acid synthesis in mice adipose tissues.

While ACC is related to fatty acid metabolism via generating malonyl-CoA for fatty acid synthesis, MCC is involved in leucine catabolism, and PC and PCC are anaplerotic, meaning they form intermediates of a metabolic pathway such as the TCA cycle [45]. Therefore, changing activities of these enzymes influence not only lipid but also carbohydrate and protein metabolism. However, in the present study, only lipid parameters were influenced by altered gene expressions of carboxylases, namely ACC, PC, PCC, and MCC.

In the present study, the magnitude of the responses was more emphasized (greater) with magnesium biotinate compared with commercial d-biotin. This effect could be attributed to the fact that magnesium biotinate is a bioavailable form of biotin and is 40 times more soluble than $\mathrm{d}$-Biotin and is more significantly absorbed into the blood and tissues in rats [46]. This idea is supported by evidence from a clinical study that showed that healthy female subjects orally supplemented with 10,40 , or $100 \mathrm{mg}$ of magnesium biotinate had dose-dependent increases of biotin levels in the blood with no adverse effects [46].

\section{Conclusions}

Results of the present work indicated that a new form of biotin, magnesium biotinate, is more effective in reducing serum lipid concentrations and in regulating gene expressions of lipid metabolism-related biomarkers compared to commercial d-biotin. Magnesium biotinate supplementation can be used to enhance biotin-dependent processes and for the prevention and treatment of conditions related to biotin deficiency. 


\section{Abbreviations}

SREBP-1c: Sterol regulatory element-binding protein 1; FAS: Fatty acid synthase; AMPK-a1: AMP-activated protein kinase-a1; ACC-1: Acetyl-CoA carboxylase 1; ACC-2: Acetyl-CoA carboxylase 2; PC: Pyruvate carboxylase; PCC: Propionyl-CoA carboxylase; MCC: Mutated in colorectal cancers; ALT: Alanin aminotransferaz; AST: Aspartat Aminotransferaz; cGMP: Cyclic guanosine monophosphate; GCC: Geranyl-CoA carboxylase; LCC: Long-chain acyl-CoA carboxylase; UC: Urea carboxylase; SREBPs: Sterol regulatory element-binding proteins; AMPK: AMP-activated protein kinase; RDA: U.S Recommended Dietary Allowance; IRS-1: Insulin receptor substrate 1; MDA: Malondialdehyde; BW: Body weight; MB: Magnesium biotinate; IgG: Immunoglobulin G; VLDL cholesterol: Very-low-density lipoprotein cholesterol TCA cycle: Tricarboxylic acid cycle

\section{Declarations}

\section{Acknowledgments}

The authors thank Nutrition 21, LLC (Purchase, NY, USA) and Turkish Academy of Sciences (Ankara, Turkey; KS) for the supporting this study.

\section{Authors' contributions}

KS designed the experiments. CO, MT and NS carried out the experiments. CO, MT and NS analyzed the experimental results. $\mathrm{CO}$ and $\mathrm{OK}$ conducted the statistical analysis. JK, and SPO wrote the draft manuscript; KS and OK wrote the manuscript. All the authors read and approved the final manuscript.

\section{Funding}

Funding for this study was provided by Nutrition 21, LLC (Purchase, NY, USA) through a restricted grant. This work was also supported in part by the Turkish Academy of Sciences (Ankara, Turkey; KS). The funders had no role in the project design, data collection, data analyses, and interpretation.

\section{Availability of data and materials}

All the data generated or analyzed during this study are included in this published article.

\section{Ethics approval and consent to participate}

The Animal Experimentation Ethics Committee of Firat University (2017/84-166) approved this study. 


\section{Consent for publication}

Not applicable.

\section{Competing interests}

JK and SPO are employees of Nutrition 21 LLC, NY, USA. The remaining authors state no conflict of interest.

\section{References}

1. Knowles JR. The mechanism of biotin-dependent enzymes. Annu Rev Biochem. 1989;58:195-221.

2. Mock D. Biotin: physiology, dietary sources and requirements. In: Caballero B, Allen L, Prentice A (eds) Encyclopedia of human nutrition, 2nd edn. Academic, London; 2004.

3. Zempleni J. Uptake, localization, and noncarboxylase roles of biotin. Annu Rev Nutr. 2005;25:175-96.

4. Revilla-Monsalve C, Zendejas-Ruiz I, Islas-Andrade S, Báez-Saldaña A, Palomino-Garibay MA, Hernández-Quiróz PM, et al. Biotin supplementation reduces plasma triacylglycerol and VLDL in type 2 diabetic patients and in nondiabetic subjects with hypertriglyceridemia. Biomed Pharmacother. 2006;60:182-85.

5. Larrieta E, Velasco F, Vital P, López-Aceves T, Lazo-de-la-Vega-Monroy ML, Rojas A, et al. Pharmacological concentrations of biotin reduce serum triglycerides and the expression of lipogenic genes. Eur J Pharmacol. 2010;644:263-68.

6. Aguilera-Mendez A, Fernandez-Mejia C. The hypotriglyceridemic effect of biotin supplementation involves increased levels of cGMP and AMPK activation. Biofactors. 2012;38:387-94.

7. Suchy SF, Rizzo WB, Wolf B. Effect of biotin deficiency and supplementation on lipid metabolism in rats: saturated fatty acids. Am J Clin Nutr. 1986;44:475-80.

8. Sahin K, Tuzcu M, Orhan C, Sahin N, Kucuk O, Ozercan IH, et al. Anti-diabetic activity of chromium picolinate and biotin in rats with type 2 diabetes induced by high-fat diet and streptozotocin. $\mathrm{Br} \mathrm{J}$ Nutr. 2013;110(2):197-205.

9. Boone-Villa D, Aguilera-Méndez A, Miranda-Cervantes A, Fernandez-Mejia C. Effects of biotin supplementation in the diet on adipose tissue cGMP concentrations, AMPK activation, lipolysis, and serum-free fatty acid levels. J Med Food. 2015;18:1150-56.

10. Tong L. Structure and function of biotin-dependent carboxylases. Cell Mol Life Sci. 2013;70(5):86391.

11. Saggerson D. Malonyl-CoA, a key signaling molecule in mammalian cells. Annu Rev Nutr. 2008;28:253-72.

12. Jitrapakdee S, St Maurice M, Rayment I, Cleland WW, Wallace JC, Attwood PV. Structure, mechanism and regulation of pyruvate carboxylase. Biochem J Biochem J. 2008;1:413(3): 369-87. 
13. Chu $\mathrm{C}-\mathrm{H}$, Cheng D. Expression, purification, characterization of human 3-methylcrotonyl-CoA carboxylase (MCCC). Prot Expr Purif. 2007;53:421-27.

14. Shimano H. Sterol regulatory element-binding proteins (SREBPs): transcriptional regulators of lipid synthetic genes. Prog Lipid Res. 2001;40(6):439-52.

15. Chirala SS, Wakil SJ. Structure and function of animal fatty acid synthase. Lipids. 2004;39(11):104553.

16. Kim J, Yang G, Kim Y, Kim J, Ha J. AMPK activators: mechanisms of action and physiological activities. Exp Mol Med. 2016;48(4):e224.

17. De la Vega L, Stockert R. Regulation of the insulin and asialoglycoprotein receptors via cGMPdependent protein kinase. Am J Physiol Cell Physiol. 2000;279:C2037-42.

18. Myers SA, Nield A, Myers M. Zinc transporters, mechanisms of action and therapeutic utility: implication for type2 diabetes mellitus. J Nutr Metab. 2012;2012:173712.

19. Larrieta E, Vega-Monroy ML, Vital P, Aguilera A, German MS, Hafidi ME, et al. Effects of biotin deficiency on pancreatic islet morphology, insulin sensitivity and glucose homeostasis. J Nut Biochem. 2012;23:392-99.

20. Yoshikawa H, Tajiri Y, Sako Y, Hashimoto T, Umeda F, Nawata H. Effects of biotin on glucotoxicity or lipotoxicity in rat pancreatic islets. Metab Clin Exp. 2002;51(2):163-68.

21. Maebashi M, Mankino Y, Furukawa Y. Therapeutic evaluation of the effect of biotin on hyperglycemia in patient with NIDDM. Clin Biochem Nutr. 1993;14:211-18.

22. Zempleni J, Mock DM. Biotin biochemistry and human requirements. J Nutr Biochem. 1999;10(3):128-38.

23. Turgut $M$, Cinar V, Pala R, Tuzcu M, Orhan $\mathrm{C}$, Telceken $\mathrm{H}$, et al. Biotin and chromium histidinate improve glucose metabolism and proteins expression levels of IRS-1, PPAR- $\gamma$, and NF-KB in exercisetrained rats. J Int Soc Sports Nutr. 2018;15(1):45.

24. Tourbah A, Lebrun-Frenay C, Edan G, Clanet M, Papeix C, Vukusic S, et al. MD1003 (high-dose biotin) for the treatment of progressive multiple sclerosis: A randomised, double-blind, placebo controlled study. Mult Scler. 2016;22(13):1719-31.

25. Perez Ojalvo S, Sylla S, Komorowski J, Orhan C, Tuzcu M, Sahin N, et al. The safety and absorption of magnesium biotinate in rats. Curr Dev Nutr. 2019;3(1):P06-029-19.

26. Mock DM. Determinations of biotin in biological fluids. Meth Enzymol. 1997;279:265-75.

27. Lewis B, Rathman S, McMahon R. Dietary biotin intake modulates the pool of free and protein-bound biotin in rat liver. J Nutr. 2001;131:2310-15.

28. Giorgi MG, Howland K, Martin C, Bonner AB. A novel HPLC method for the concurrent analysis and quantitation of seven water-soluble vitamins in biological fluids (plasma and urine): a validation study and application. ScientificWorldJournal. 2012;2012:359721.

29. Sahin K, Orhan C, Akdemir F, Tuzcu M, Sahin N, YIlmaz I, Juturu V. $\beta$-Cryptoxanthin ameliorates metabolic risk factors by regulating NF-KB and Nrf2 pathways in insulin resistance induced by high- 
fat diet in rodents. Food Chem Toxicol. 2017 Sep;107(Pt A):270-279.

30. Lazo de la Vega-Monroy ML, Larrieta E, German MS, Baez-Saldana A, Fernandez-Mejia C. Effects of biotin supplementation in the diet on insulin secretion, islet gene expression, glucose homeostasis and beta-cell proportion. J Nutr Biochem. 2013;24(1):169-77.

31. Riverón-Negrete L, Sicilia-Argumedo G, Álvarez-Delgado C, Coballase-Urrutia E, Alcántar-Fernández J, Fernandez-Mejia C. Dietary biotin supplementation modifies hepatic morphology without changes in liver toxicity markers. Biomed Res Int. 2016;2016:7276463.

32. Baez-Saldana A, Zendejas-Ruiz I, Revilla-Monsalve C, Islas-Andrade S, Cárdenas A, Rojas-Ochoa A, et al. Effects of biotin on pyruvate carboxylase, acetyl-CoA carboxylase, propionyl-CoA carboxylase, and markers for glucose and lipid homeostasis in type 2 diabetic patients and nondiabetic subjects. Am J Clin Nutr. 2004;79(2):238-43.

33. Vilches-Flores A, Tovar AR, Marin-Hernandez A, Rojas-Ochoa A, Fernandez-Mejia C. Biotin increases glucokinase expression via soluble guanylate cyclase/protein kinase $\mathrm{G}$, adenosine triphosphate production and autocrine action of insulin in pancreatic rat islets. J Nutr Biochem. 2009;21:606-12.

34. Tixi-Verdugo W, Contreras-Ramos J, Sicilia-Argumedo G, German MS, Fernandez-Mejia C. Effects of biotin supplementation during the first week postweaning increases pancreatic islet area, beta-cell proportion, islets number, and beta-cell proliferation. J Med Food. 2018;21(3):274-81.

35. Fernandez-Mejia C. Pharmacological effects of biotin. J Nutr Biochem. 2005;1:424-27.

36. Li Z, Zhang H. Reprogramming of glucose, fatty acid and amino acid metabolism for cancer progression. Cell Mol Life Sci. 2016;73(2):377-92.

37. Weber S, Zeller M, Guan K, Wunder F, Wagner M, El-Armouche A. PDE2 at the crossway between cAMP and cGMP signaling in the heart. Cell Signal. 2017;38:76-84.

38. McCarty MF. cGMP may have trophic effects on beta cell function comparable to those of cAMP, implying a role for high-dose biotin in prevention/treatment of diabetes. Med Hypotheses. 2006;66(2):323-8.

39. Wang Y, Viscarra J, Kim SJ, Sul HS. Transcriptional regulation of hepatic lipogenesis. Nat Rev Mol Cell Biol. 2016;17(1):64. Nat Rev Mol Cell Biol. 2015;16(11):678-689.

40. Jianhua $L$, Xueqin $M$, Jifen $H$. Expression and clinical significance of LXRa and SREBP-1c in placentas of preeclampsia. Open Med (Wars). 2016;11(1):292-96.

41. Shimano H. SREBPs: physiology and pathophysiology of the SREBP family. FEBS J. 2009;276(3):616-21.

42. Imai N, Cohen DE. Trimming the fat: Acetyl-CoA carboxylase inhibition for the management of NAFLD. Hepatology. 2018;68(6):2062-65.

43. Davies SP, Sim AT, Hardie DG. Location and function of three sites phosphorylated on rat acetyl-CoA carboxylase by the AMP-activated protein kinase. Eur J Biochem 1990;187:183-90.

44. Moreno-Méndez E, Hernández-Vázquez A, Fernández-Mejía C. Effect of biotin supplementation on fatty acid metabolic pathways in 3T3-L1 adipocytes. Biofactors. 2019;45(2):259-70. 
45. Gibala MJ, Young ME, Taegtmeyer $\mathrm{H}$. Anaplerosis of the citric acid cycle: role in energy metabolism of heart and skeletal muscle. Acta Physiol Scand. 2000;168:657-65.

46. Ojalvo SP, Sylla S, Komorowski J. Pharmacokinetics of a Novel Form of Biotin, Magnesium Biotinate, in Healthy Subjects (P06-027-19). Curr Dev Nutr. 2019;(Suppl 1):nzz031.P06-027-19. Published online 2019.

\section{Figures}


A

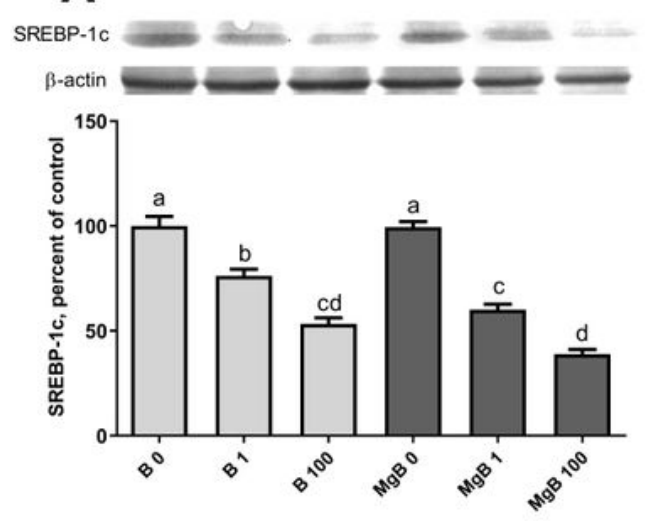

C

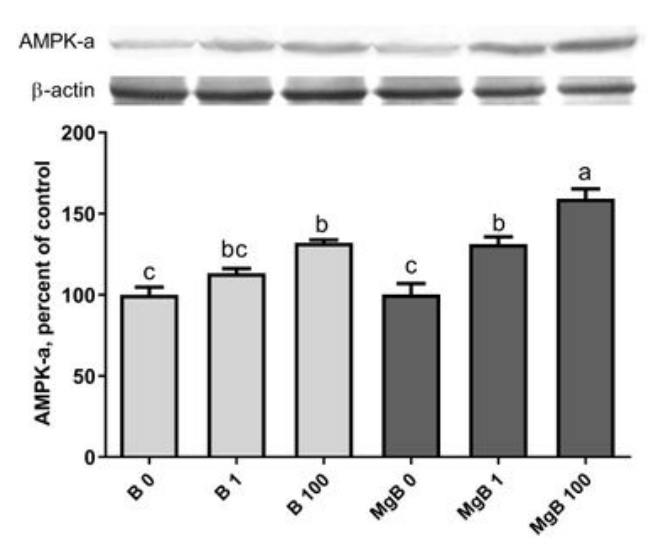

\section{B}

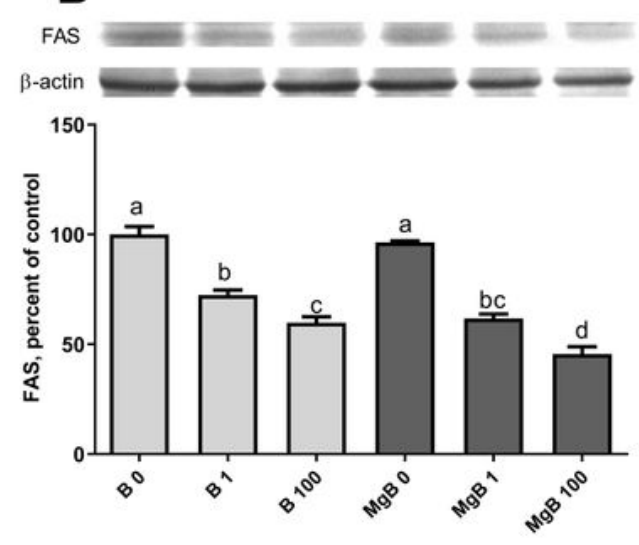

\section{Figure 1}

Effects of biotin supplementation as the commercial form or a new form (magnesium biotinate) on liver gene expression of sterol regulatory element-binding proteins (SREBP-1c) (A), Fatty acid synthase (FAS) (B), and AMP-activated protein kinase (AMPK-alpha1) (C). Dietary treatments contained biotin supplements as either commercial biotin (d-biotin) at 0.01 (B0), 1 (B1) and 100 (B100) mg/kg body weight or a new form of biotin (magnesium biotinate) at 0.01 (MgB0), 1 (MgB1), and 100 (MgB100) 
$\mathrm{mg} / \mathrm{kg}$ body weight. The doses used at $0.01,1$, and $100 \mathrm{mg}$ of biotin supplementations from each source represented standard dietary dose (control), high dietary dose, and pharmacologic dose, respectively. Statistical comparisons are indicated with different superscript $(a-c)$ in the same row $(P<0.05$; *ANOVA and Tukey's post-hoc test).
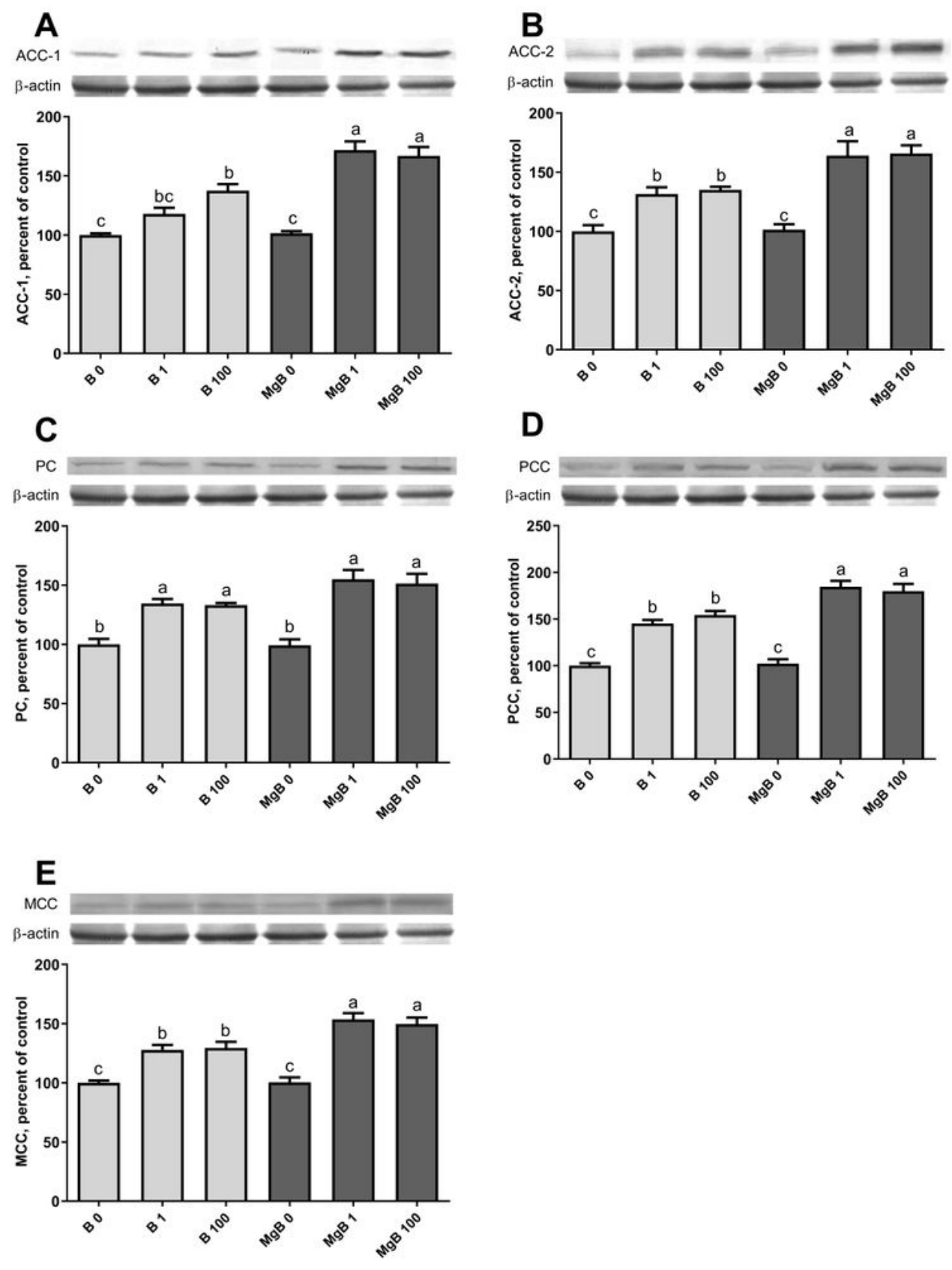

Figure 2 
Effects of biotin supplementation as the commercial form or a new form (magnesium biotinate) on liver gene expression of biotin-dependent carboxylases including; A: acetyl CoA carboxylase-1 (ACC-1), B:

acetyl CoA carboxylase-2 (ACC-2), C: pyruvate carboxylase (PC), D: propionyl CoA carboxylase (PCC), and E: 3-methylcrotonyl-CoA carboxylase (MCC). Dietary treatments contained biotin supplements as either commercial biotin (d-biotin) at 0.01 (B0), 1 (B1) and 100 (B100) mg/kg body weight or a new form of biotin (magnesium biotinate) at 0.01 (MgB0), 1 (MgB1), and 100 (MgB100) mg/kg body weight. The doses used at $0.01,1$, and $100 \mathrm{mg}$ of biotin supplementations from each source represented standard dietary dose (control), high dietary dose, and pharmacologic dose, respectively. Statistical comparisons are indicated with different superscript $(\mathrm{a}-\mathrm{c})$ in the same row $\left(\mathrm{P}<0.05 ;{ }^{*}\right.$ ANOVA and Tukey's post-hoc test). 